\title{
Temperature data analysis of the vaccine cold chain system in northern part of Thailand.
}

\author{
Kannika $\mathbf{T}^{1 *}$, Nopphadol $\mathbf{C}^{1}$, Siriporn $\mathbf{W}^{2}$ \\ 1Department of Pharmacy, Chiang Mai University, Chiang Mai, Thailand \\ 2National Health Security Office (NHSO) Region 1, Chiang Mai, Thailand
}

\begin{abstract}
Background information: Vaccines are temperature-sensitive biological preparations, $2-8^{\circ} \mathrm{C}$ or cold chain period were the appropriate range. The change of the temperature during transport system might be effect to vaccines quality assurance.

Purpose: This descriptive study was to analyze the data temperature of Diphtheria-TetanusPertussis and Hepatitis B vaccine, DPT-HB vaccine in cold chain system in fiscal year 2011-2012. We aimed to find the factor that effected to vaccine cold chain system, such as area of vaccine transport, seasonal and type of health care unit.

Method: Temperature data of DPT-HB vaccine that supplied to health care units in National Health Security Office (NHSO) Region 1 area, included 8 provinces in northern part of Thailand were analyzed. The temperature data were collected by computerized data logger and analyzed by SPSS for window version 17.0 and Logtag analyzer program.

Result: Temperature data from 322 health care units were analyzed. Most of data (40.4\%) was from Lamphun province. Most temperature data was collected from Primary Care Unit; PCU in both fiscal years. The highest number of temperature data was reported in October of fiscal year 2011 and in February of fiscal year 2012. Most of the health care worker did not set the computerize data logger follow the direction. The period of time setting data logger was very fluctuates. In fiscal year 2011, DPT-HB vaccine temperature had lower than $2^{\circ} \mathrm{C}$ at $86.9 \%$, higher than $8^{\circ} \mathrm{C}$ at $90.4 \%$ and in fiscal year 2012, DPT-HB vaccine temperature had lower than $2^{\circ} \mathrm{C}$ at $78.5 \%$, higher than $8^{\circ} \mathrm{C}$ at $92.5 \%$. Type of health care unit did not effect to vaccine's temperature monitor but seasonal had significant effect. Health care units were well developed ability in usage the computerize data logger from fiscal year 2011 to year 2012, especially in the period lower than $2^{\circ} \mathrm{C}$.

Conclusion: Type of health care unit did not effect to vaccine's temperature control following the World Health Organization criteria. Seasonal had significant effect to vaccine's temperature control. The study also found that most of the health care worker did not follow the handout of computerize data logger. Based on the study results, adequate equipment, provide training and supervision about new and current computerize data logger were recommended to support to maximize the efficacy and effectiveness of vaccine and cold chain monitoring in health care unit.
\end{abstract}

Keywords: Vaccine, Cold chain, Data logger, DPT-HB.

Accepted on July 11, 2018

\section{Introduction and Background}

Vaccines are temperature-sensitive biological products that stimulate the immune system of the recipient, whether human or animal, to immunize against pathogens, toxins, or biomolecules, which can reduce or prevent disease. The system used for storing vaccines in good condition is called the cold chain. The objective of the vaccine cold chain is to maintain product quality from the time of manufacture until the point of administration by ensuring that vaccines are stored and transported within World Health Organization-WHO recommended temperature ranges [1]. To maintain efficacy, vaccines must be protected from temperature extremes. Vaccine quality is maintained using a cold chain that meets specific temperature requirements. At the health facility level, WHO recommend that health workers can adequately protect vaccines by keep vaccines in appropriate vaccine refrigeration equipment, use a temperature monitoring device to ensure temperatures remain between $+2^{\circ} \mathrm{C}$ and $+8^{\circ} \mathrm{C}$, transport vaccines to immunization sessions in a vaccine carrier, correctly packed, using coolant packs that have been properly prepared, and during immunization sessions, fit a foam pad (if available) at the top of the vaccine carrier.

Diphtheria-Tetanus-Pertussis (whooping cough) and Hepatitis $B$ vaccine, DPT- HB vaccine confers immunity to diphtheria, tetanus, pertussis and hepatitis B. DTP vaccine conveys immunity to four different infectious diseases, Diphtheria is a potentially fatal disease that usually involves the nose, throat, 
and air passages [2]. Its most prominent feature is the formation of a grayish membrane covering the tonsils and upper part of the throat. It is caused by Corynebacterium diphtheriae. Tetanus, or lockjaw, is a disease caused by the toxin of Clostridium tetani, affects the central nervous system and causes painful muscle contractions. Tetanus is often fatal.

Pertussis, or whooping cough, is a respiratory disease caused by Bordatella pertussis, with a typical cough which starts with a deep inhalation, followed by a series of quick, short coughs that continues until the air is expelled from the lungs, and ends with a long shrill, whooping inhalation [3]. Pertussis is very contagious and usually affects young children. Hepatitis is an inflammation of the liver that can be self-limiting or can progress to fibrosis (scarring), cirrhosis or liver cancer.

Hepatitis B virus (HBV) is transmitted through exposure to infective blood, semen, and other body fluids. HBV can be transmitted from infected mothers to infants at the time of birth or from family member to infant in early childhood [4]. Safe and effective vaccines are available to prevent HBV. DPT$\mathrm{HB}$ vaccine which is labeled for storage in cold chain system, between +2 and $+8^{\circ} \mathrm{C}$.

\section{Aims}

This descriptive study was to analyze the data temperature of DPT- HB vaccine in cold chain system. We aimed to find the factor that effected to the change of vaccine's temperature before used, such as area of vaccine transport, seasonal and type of health care unit.

\section{Scope of Study}

Temperature data of DPT-HB vaccine that supplied to health care units in National Health Security Office (NHSO) Region 1 area, included 8 provinces in northern part of Thailand in fiscal year 2011-2012, in the period of October 2011-September 2013, were analyzed [5].

\section{Methods}

The temperature data were collected by computerized data logger and analyzed by SPSS for window version 17.0 and Logtag analyzer program.

\section{Definition}

\section{Vaccine}

It means temperature-sensitive biological products that stimulate the immune system of the recipient to immunize against pathogens, toxins, or biomolecules, which can reduce or prevent disease.

\section{Cold chain}

It means the system used for storing vaccines in good condition, to maintain vaccine quality from the time of manufacture until the point of administration.

\section{Data logger}

It means electronic devices which automatically monitor and record environmental parameters over time, allowing conditions to be measured, documented, analyzed and validated. The data logger contains a sensor to receive the information and a computer chip to store it. Then the information stored in the data logger is transferred to a computer for analysis. In this study, Data logger means LogTag Trix-8 [6].

\section{Vendor managed inventory (VMI)}

It means optimizing Supply Chain performance in which the manufacturer is responsible for maintaining the distributor's inventory levels. The manufacturer has access to the distributor's inventory data and is responsible for generating purchase orders.

\section{Primary care unit (PCU)}

It means smallest unit of health care that provide primary care for villagers.

\section{Contracting unit for primary care (CUP)}

It means main Contractor of Primary Care Unit.

\section{DPT-HB vaccine}

It means vaccine that conveys immunity to four different infectious diseases, diphtheria, tetanus, pertussis and hepatitis B.

\section{Seasonal}

It means summer in the period from March to June, rainy in the period from July to October and winter in the period from November to February [7].

\section{Results and Discussion}

Temperature data of DPT-HB vaccine that supplied to health care units in National Health Security Office (NHSO) Region 1 area, included 8 provinces in northern part of Thailand, Chiang Mai, Chiang Rai, Lampang, Mae Hong Son, Phrae, Nan, Lamphun and Phayao Province, were analyzed.

Table 1 shows that 1,198 health care units that used data logger with 322 health care units sending data back to National Health Security Office (NHSO) Region 1 area, return rate of data was $26.9 \%$, most of data that sending back to National Health Security Office (NHSO) Region 1 area at 40.4\% from health care units in Lamphun province and the last that the data from health care units in Mae Hong Son province at 12.2\%.

General information of Contracting Unit for Primary Care; CUP and Primary Care Unit; PCU with data logger and number of data in fiscal year 2011-2012 by province and month were shown in Table 2. Most temperature data was collected from Primary Care Unit; PCU and from Chiang Rai province in both fiscal year [8-10]. The highest number of temperature data was reported in October of fiscal year 2011 and in February of fiscal year 2012 .

Table 3 shows varies time period for setting data logger, most at the period of 1 hour, in fiscal year 2011, DPT-HB vaccine temperature had lower than $2^{\circ} \mathrm{C}$ at $86.9 \%$, higher than $8^{\circ} \mathrm{C}$ at $90.4 \%$ and in fiscal year 2012 , DPT-HB vaccine temperature had lower than $2^{\circ} \mathrm{C}$ at $78.5 \%$, higher than $8^{\circ} \mathrm{C}$ at $92.5 \%$.

\section{Factor effected to the change of vaccine's temperature}

Temperature data outside cold chain period, lower than $2^{\circ} \mathrm{C}$ and higher than $8^{\circ} \mathrm{C}$, by province were shown in Figures 1 and 2 . 
Table 1. Number of primary care unit and contracting unit for primary care in each province and number of return data to NHSO in fiscal year 2011-2012.

\begin{tabular}{|c|c|c|c|}
\hline \multirow[t]{2}{*}{ Province } & \multirow[t]{2}{*}{ Number of health care units with data logger } & \multicolumn{2}{|c|}{ Return of data } \\
\hline & & Number & Percent \\
\hline Chiang Rai & 214 & 79 & 40 \\
\hline Mae Hong Son & 49 & 6 & 12.2 \\
\hline Lampang & 134 & 41 & 30.6 \\
\hline Lamphun & 52 & 21 & 40.4 \\
\hline Chiang Mai & 373 & 57 & 15.3 \\
\hline Phayao & 90 & 36 & 40 \\
\hline Nan & 141 & 55 & 39 \\
\hline Phrae & 145 & 27 & 18.6 \\
\hline Total & 1,198 & 322 & 26.9 \\
\hline
\end{tabular}

Table 2. General information of contracting unit for primary care; CUP and primary care unit; PCU with data logger.

\begin{tabular}{|c|c|c|c|c|}
\hline \multirow[t]{2}{*}{ General information } & \multicolumn{2}{|c|}{2011} & \multicolumn{2}{|c|}{2012} \\
\hline & Frequency & Percent & Frequency & Percent \\
\hline \multicolumn{5}{|l|}{ Number of data from Data logger from } \\
\hline Contracting Unit for Primary Care; CUP & 31 & 9.6 & 105 & 7.5 \\
\hline Primary Care Unit; PCU & 292 & 90.4 & 1294 & 92.5 \\
\hline \multicolumn{5}{|l|}{ Number of data from Data logger in province } \\
\hline Chiang Rai & 58 & 17.9 & 358 & 25.6 \\
\hline Mae Hong Son & 35 & 10.8 & 31 & 2.2 \\
\hline Lampang & 39 & 12.1 & 185 & 13.2 \\
\hline Lamphun & 29 & 9.0 & 83 & 5.9 \\
\hline Chiang Mai & 35 & 10.8 & 270 & 19.3 \\
\hline Phayao & 48 & 14.9 & 183 & 13.1 \\
\hline Nan & 50 & 15.5 & 174 & 12.5 \\
\hline Phrae & 29 & 9.0 & 115 & 8.2 \\
\hline \multicolumn{5}{|l|}{ Month } \\
\hline September & 25 & 7.8 & 107 & 7.6 \\
\hline October & 88 & 27.2 & 102 & 7.3 \\
\hline November & 87 & 26.9 & 114 & 8.1 \\
\hline December & 67 & 20.8 & 144 & 10.3 \\
\hline January & 34 & 10.5 & 13 & 9.4 \\
\hline February & 20 & 6.2 & 147 & 10.5 \\
\hline March & 2 & 0.6 & 140 & 10 \\
\hline April & 0 & 0 & 135 & 9.7 \\
\hline May & 0 & 0 & 114 & 8.2 \\
\hline June & 0 & 0 & 98 & 7.0 \\
\hline July & 0 & 0 & 49 & 3.5 \\
\hline August & 0 & 0 & 118 & 8.4 \\
\hline
\end{tabular}

Table 3. Data logger character of time period for record temperature and number of data outside cold chain period.

\begin{tabular}{|c|c|c|c|c|}
\hline \multirow[t]{2}{*}{ Character } & \multicolumn{2}{|c|}{2011} & \multicolumn{2}{|c|}{2012} \\
\hline & Frequency & Percent & Frequency & Percent \\
\hline \multicolumn{5}{|l|}{ Time period for record temperature } \\
\hline 3 minute & 0 & 0 & 1 & 0.1 \\
\hline 5 minute & 23 & 7.1 & 145 & 10.3 \\
\hline 6 minute & 0 & 0 & 76 & 5.4 \\
\hline 7 minute & 0 & 0 & 77 & 5.5 \\
\hline 10 minute & 8 & 2.5 & 60 & 4.3 \\
\hline 11 minute & 0 & 0 & 55 & 3.9 \\
\hline 20 minute & 0 & 0 & 166 & 11.9 \\
\hline 30 minute & 39 & 12.1 & 252 & 18 \\
\hline 1 hour & 253 & 78.3 & 565 & 40.4 \\
\hline 3 hour & 0 & 0 & 1 & 0.1 \\
\hline 18 Hour 8 Second & 0 & 0 & 1 & 0.1 \\
\hline \multicolumn{5}{|l|}{ Temperature } \\
\hline Lower than $+2^{\circ} \mathrm{C}$ & 281 & 86.9 & 1,099 & 78.5 \\
\hline Higher than $+8^{\circ} \mathrm{C}$ & 291 & 90.4 & 93 & 92.5 \\
\hline
\end{tabular}


Relationship between type of health care unit and percent of temperature data lower than $2^{\circ} \mathrm{C}$ and higher than $8^{\circ} \mathrm{C}$, were shown in Tables 4 and 5.

Figures 1 and 2 show temperature data outside cold chain period, lower than $2^{\circ} \mathrm{C}$ and higher than $8^{\circ} \mathrm{C}$, by province.

Percent of temperature data lower than $2^{\circ} \mathrm{C}$ of Contracting Unit for Primary Care; CUP was significantly different from percent of temperature data of Primary Care Unit; PCU in fiscal year 2012, $\mathrm{p}=0.001$, but did not significantly in fiscal year 2011, $\mathrm{p}=0.335$ [11-17].

Table 4. Relationship between type of health care unit and percent of temperature data lower than $2^{\circ} \mathrm{C}$.

\begin{tabular}{|l|c|c|}
\hline Type of health care unit & $\begin{array}{c}\text { Median } \\
\text { (interquartile range) }\end{array}$ & P-value* \\
\hline Fiscal year 2011 & & \\
\hline Contracting Unit for Primary Care; CUP & $2.8(21.2)$ & 0.335 \\
\hline Primary Care Unit; PCU & $2.9(33.6)$ & \\
\hline Fiscal year 2012 & & \\
\hline Contracting Unit for Primary Care; CUP & $0.0(1.3)$ & 0.001 \\
\hline Primary Care Unit; PCU & $0.9(8.2)$ & \\
\hline *Mann-Whitney U Test & & \\
\hline
\end{tabular}

Percent of temperature data higher than $8^{\circ} \mathrm{C}$ of Contracting Unit for Primary Care; CUP did not significantly different from percent of temperature data of Primary Care Unit; PCU in both fiscal year 2011, and 2012 ( $\mathrm{p}=0.747$ and 0.073 respectively).

Focus on seasonal effect to vaccine temperature control, the result show that in fiscal year 2011, percent of temperature data higher than $8^{\circ} \mathrm{C}$ in rainy season was only significantly different from percent of temperature data higher than $8^{\circ} \mathrm{C}$ in winter season, show in Table 6.

In fiscal year 2012, percent of temperature data lower than $2^{\circ} \mathrm{C}$

Table 5. Relationship between type of health care unit and percent of temperature data higher than $8^{\circ} \mathrm{C}$

\begin{tabular}{|l|c|c|}
\hline Type of health care unit & $\begin{array}{c}\text { Median } \\
\text { (interquartile range) }\end{array}$ & P-value* \\
\hline Fiscal year $\mathbf{2 0 1 1}$ & & \\
\hline Contracting Unit for Primary Care; CUP & $0.7(11.4)$ & 0.747 \\
\hline Primary Care Unit; PCU & $1.1(8.3)$ & \\
\hline Fiscal year 2012 & & \\
\hline Contracting Unit for Primary Care; CUP & $0.3(1.3)$ & 0.073 \\
\hline Primary Care Unit; PCU & $0.6(3.2)$ & \\
\hline *Mann-Whitney U Test & & \\
\hline
\end{tabular}

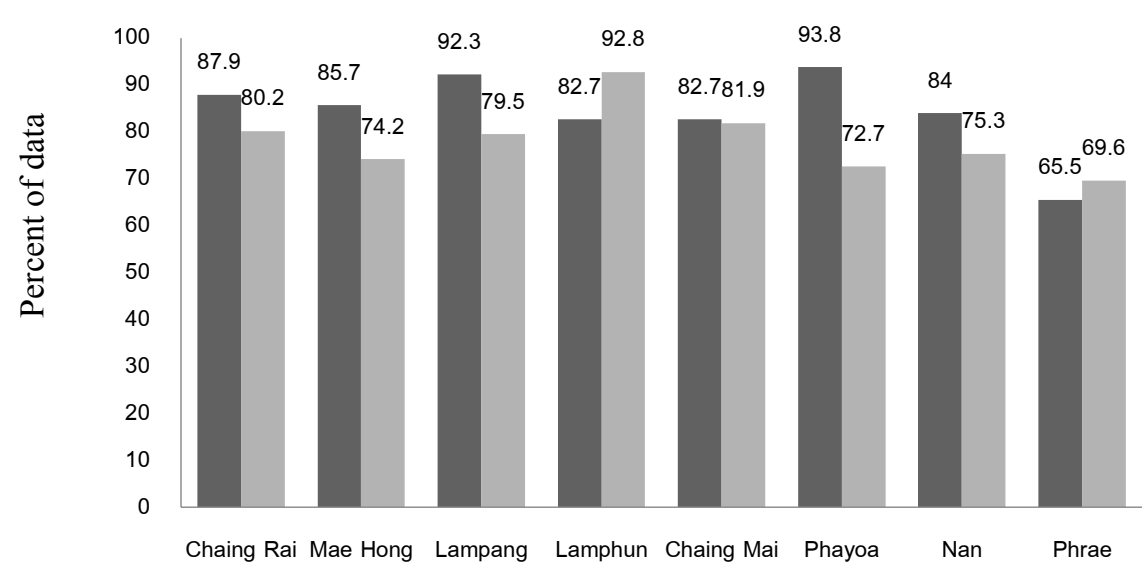

Son

$2011-2012$

Figure 1. Percent of temperature data lower than $2^{\circ} \mathrm{C}$ by province.

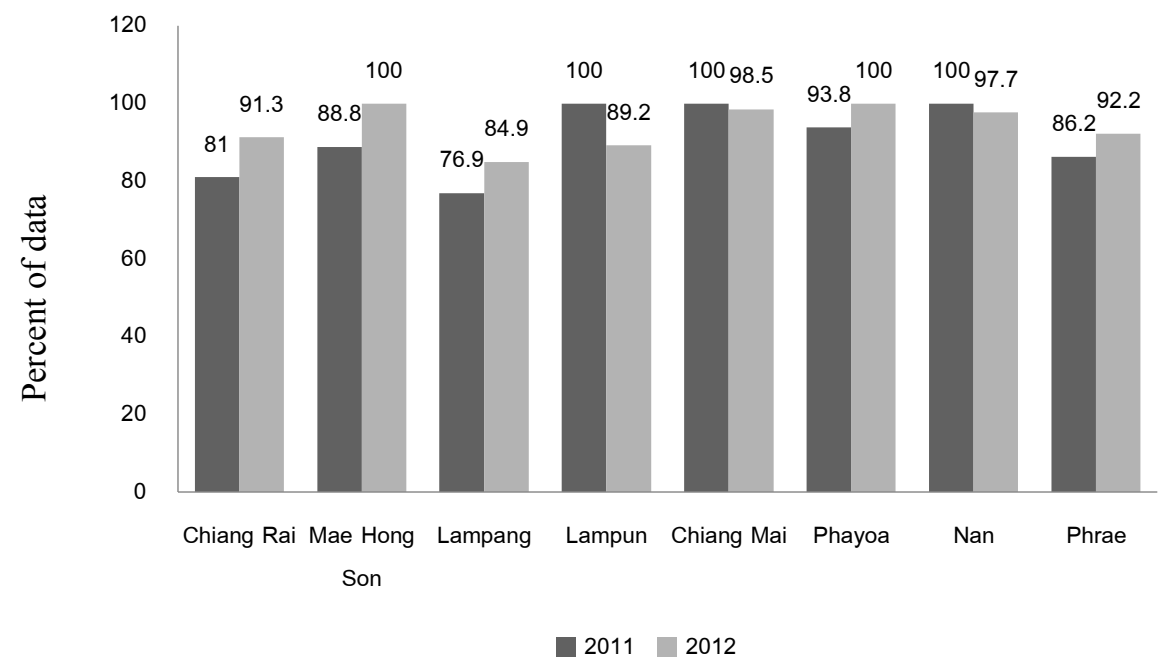

Figure 2. Percent of temperature data higher than $8^{\circ} \mathrm{C}$ by province. 
in summer season was significantly different from percent of temperature data lower than $2^{\circ} \mathrm{C}$ in rainy season, rainy season with winter season and summer season with winter season, show in Tables 7-9.

Percent of temperature data higher than $8^{\circ} \mathrm{C}$ in fiscal year 2012 , in rainy season was significantly different from percent of temperature data higher than $8^{\circ} \mathrm{C}$ in winter season, $\mathrm{p}=0.001$, show in Table 10 and in summer season was significantly different from percent of temperature data higher than $8^{\circ} \mathrm{C}$ in winter season, $\mathrm{p}=0.001$, show in Table 11 .

\section{Conclusions}

Temperature data of DTB-HepB Vaccine from 322 health care units sending back to National Health Security Office (NHSO) Region 1 area in final year 2011-2012, return rate of data was $26.9 \%$. Most of data $(40.4 \%)$ was from health care units in

Table 6. Relationship between percent of temperature data higher than $8^{\circ} \mathrm{C}$ in rainy and winter season in fiscal year 2011.

\begin{tabular}{|l|c|c|}
\hline Seasonal & $\begin{array}{c}\text { Median } \\
\text { (interquartile range) }\end{array}$ & P-value* \\
\hline Rainy & $2.4(14.7)$ & 0.001 \\
\hline Winter & $0.6(5.3)$ & \\
\hline${ }^{*}$ Mann-Whitney U Test & & \\
\hline
\end{tabular}

Table 7. Relationship between percent of temperature data lower than $2^{\circ}$ in summer and rainy season in fiscal year 2012.

\begin{tabular}{|l|c|c|}
\hline Seasonal & $\begin{array}{c}\text { Median } \\
\text { (interquartile range) }\end{array}$ & P-value* $^{*}$ \\
\hline Summer & $0.6(3.2)$ & 0.001 \\
\hline Rainy & $2(24.6)$ & \\
\hline *Mann-Whitney U Test & & \\
\hline
\end{tabular}

Table 8. Relationship between percent of temperature data lower than $2^{\circ}$ in rainy and winter season in fiscal year 2012.

\begin{tabular}{|l|c|c|}
\hline Seasonal & $\begin{array}{c}\text { Median } \\
\text { (interquartile range) }\end{array}$ & P-value* \\
\hline Rainy & $2(24.6)$ & 0.010 \\
\hline Winter & $0.8(8.2)$ & \\
\hline *Mann-Whitney U Test & & \\
\hline
\end{tabular}

Table 9. Relationship between percent of temperature data lower than $2^{\circ}$ in summer and winter season in fiscal year 2012.

\begin{tabular}{|l|c|c|}
\hline Seasonal & $\begin{array}{c}\text { Median } \\
\text { (interquartile range) }\end{array}$ & P-value* $^{*}$ \\
\hline Summer & $0.6(3.2)$ & 0.016 \\
\hline Winter & $0.8(8.2)$ & \\
\hline *Mann-Whitney U Test & & \\
\hline
\end{tabular}

Table 10. Relationship between percent of temperature data higher than $8^{\circ} \mathrm{C}$ in summer and winter season in fiscal year 2012.

\begin{tabular}{|l|c|c|}
\hline Seasonal & $\begin{array}{c}\text { Median } \\
\text { (interquartile range) }\end{array}$ & P-value* $^{*}$ \\
\hline Summer & $0.7(3.2)$ & 0.001 \\
\hline Winter & $0.3(2.4)$ & \\
\hline${ }^{*}$ Mann-Whitney U Test & & \\
\hline
\end{tabular}

Table 11. Relationship between percent of temperature data higher than $8^{\circ} \mathrm{C}$ in rainy and winter season in fiscal year 2012 .

\begin{tabular}{|l|c|c|}
\hline Seasonal & $\begin{array}{c}\text { Median } \\
\text { (interquartile range) }\end{array}$ & P-value* \\
\hline Rainy & $0.8(3.3)$ & 0.001 \\
\hline Winter & $0.3(2.4)$ & \\
\hline *Mann-Whitney U Test & & \\
\hline
\end{tabular}

Lamphun province and the last from Mae Hong Son province at $12.2 \%$. Most temperature data was collected from Primary Care Unit; PCU in both fiscal year. The highest number of temperature data was reported in October of fiscal year 2011 and in February of fiscal year 2012. The study also found that most of the health care worker did not set the computerize data logger follow the direction. The period of time for setting data logger were very fluctuates.

In fiscal year 2011, DPT-HB vaccine temperature had lower than $2^{\circ} \mathrm{C}$ at $86.9 \%$, higher than $8^{\circ} \mathrm{C}$ at $90.4 \%$ and in fiscal year 2012, DPT-HB vaccine temperature had lower than $2^{\circ} \mathrm{C}$ at $78.5 \%$, higher than $8^{\circ} \mathrm{C}$ at $92.5 \%$ Percent of temperature data lower than $2^{\circ} \mathrm{C}$ of Contracting Unit for Primary Care; CUP was significantly different from percent of temperature data of Primary Care Unit; PCU in fiscal year 2012, but did not significantly in fiscal year 2011.

Percent of temperature data higher than $8^{\circ} \mathrm{C}$ of Contracting Unit for Primary Care; CUP did not significantly different from percent of temperature data of Primary Care Unit; PCU in both fiscal year 2011 and 2012.

In fiscal year 2011 , percent of temperature data higher than $8^{\circ} \mathrm{C}$ in rainy season was only significantly different from percent of temperature data higher than $8^{\circ} \mathrm{C}$ in winter season

In fiscal year 2012, percent of temperature data lower than $2^{\circ} \mathrm{C}$ in summer season was significantly different from percent of temperature data lower than $2^{\circ} \mathrm{C}$ in rainy season, rainy season with winter season and summer season with winter season. Percent of temperature data higher than $8^{\circ} \mathrm{C}$ in rainy season was significantly different from percent of temperature data higher than $8^{\circ} \mathrm{C}$ in winter season and in summer season with winter season.

Both Contracting Unit for Primary Care; CUP and Primary Care Unit; PCU were well developed ability in usage the computerize data logger for monitor cold chain system from fiscal year 2011 to year 2012 , especially in the period lower than $2^{\circ} \mathrm{C}$. Seasonal, summer, rainy and winter, had significantly effect to vaccine's cold chain system, especially break down to higher than $8^{\circ} \mathrm{C}$, the same direction both in fiscal year 2011 and 2012.

Based on the study results, adequate equipment, provide training and supervision about new and current computerize data logger were recommended to support to maximize the efficacy and effectiveness of vaccine and cold chain monitoring in health care unit.

\section{References}

1. Department of Immunization, Vaccines and Other Biologicals, World Health Organization. Cold chain, vaccines and safe-injection equipment management. Geneva: WHO. 2008.

2. World Health Organization. The effects of freezing of the appearance, potency and toxicity on adsorbed and unabsorbed DTP vaccines. Weekly epidemiological record. 1980;55:385-92

3. Tharmaphornpilas $\mathrm{P}$, Yoocharoan $\mathrm{P}$, Prempree $\mathrm{P}$, et al. Diphtheria in Thailand in the 1990s. J Infect Dis. 2001;184(8):1035-40. 
4. American Academy of Pediatrics. Tetanus. In: Pickering LK, Baker CJ, Long SS, Kimberlin DW (eds.) Red Book: 2009 Report of the Committee on Infectious Diseases. (28thedn), Elk Grove Village, IL: American Academy of Pediatrics. 2009;555-60.

5. Centers for Disease Control and Prevention (CDC). Final reports of internationally notifiable diseases. MMWR Morb Mortal Wkly Rep. 2010;59:1027-39.

6. Bisgard KM, Rhodes P, Connelly BL, et al. Pertussis vaccine effectiveness among children 6 to 59 months of age in the United States, 1998-2001. Pediatrics. 2005;116(2):285-94.

7. Casey JR, Pichichero ME. Acellular pertussis vaccine safety and efficacy in children, adolescents and adults. Drugs. 2005;65(10):1367-89.

8. Kosuwon P, Warachit B, Hutagalung Y, et al. Reactogenicity and immunogenicity of reduced antigen content diphtheriatetanus-acellular pertussis vaccine (dTpa) administered as a booster to 4-6 year-old children primed with four doses of whole-cell pertussis vaccine. Vaccine. 2003;21(2730):4194-200.

9. Sänger R, Behre U, Krause KH, et al. Booster vaccination and 1-year follow-up of 4-8-year-old children with a reduced-antigen-content dTpa-IPV vaccine. Eur J Pediatr. 2007;166(12):1229-36

10. Langley JM, Predy G, Guasparini R, et al. An adolescentadult formulation tetanus and diphtheria toxoids adsorbed combined with acellular pertussis vaccine has comparable immunogenicity but less reactogenicity in children 4-6 years of age than a pediatric formulation acellular pertussis vaccine and diphtheria and tetanus toxoids adsorbed combined with inactivated poliomyelitis vaccine. Vaccine. 2007;25(6):1121-25.

11. Meyer CU, Habermehl P, Knuf M, et al. Immunogenicity and reactogenicity of acellular pertussis booster vaccines in children: standard pediatric versus a reduced-antigen content formulation. Hum Vaccin. 2008;4(3):203-09.

12. Scheifele DW, Halperin SA, Ochnio JJ, et al. A modified vaccine reduces the rate of large injection site reactions to the preschool booster dose of diphtheria-tetanus-acellular pertussis vaccine: results of a randomized, controlled trial. Pediatr Infect Dis J. 2005;24(12):1059-66.

13. Bailleux F, Coudeville L, Kolenc-Saban A, et al. Predicted long-term persistence of pertussis antibodies in adolescents after an adolescent and adult formulation combined tetanus, diphtheria, and 5-component acellular pertussis vaccine, based on mathematical modeling and 5-year observed data. Vaccine. 2008; 26(31):3903-08

14. Techathawat S, Varinsathien P, Rasdjarmrearnsook A, et al. Exposure to heat and freezing in the vaccine cold chain in Thailand. Vaccine. 2007;25(7):1328-33.

15. Briggs $H$ and Ilett $S$. Weak link in vaccine cold chain. BMJ. 1993;306(6877):557-8.

16. Nelson C, Froes P, Dyck AMV, et al. Monitoring temperatures in the vaccine cold chain in Bolivia. Vaccine. 2007;433-7.

17. Chen D, Tyagi A, Carpenter J, et al. Characterization of the freeze sensitivity of a hepatitis B vaccine. Hum Vaccin. 2009;5(1):26-32.

\section{*Correspondence to:}

Kannika T

Department of Pharmacy

Chiang Mai University

Thailand

Tel: +6653941000

E-mail: kannika.th@cmu.ac.th 